Brit. J. industr. Med., 1955, 12, 320.

\title{
DERMATITIS FROM SOLUTIONS OF SODIUM AND CALCIUM CHLORIDE IN THE COAL-MINING INDUSTRY
}

BY

\author{
O. P. EDMONDS
}

From the National Coal Board (East Midlands Division)

(RECEIVED FOR PUBLICATION APRIL 7, 1955)

The harmful effects of salt on the skin were first described by Paracelsus (1493-1541, see Schwartz, Tulipan, and Peck, 1947), and there have been accounts since confirming this clinical observation in many industries. Ulcers of the legs occur in salt-miners (Ramazzini, 1700). Salt-water boils are found in shipwrecked sailors and deep-sea fishermen (Critchley, 1943) ; dock labourers carrying bags of salt develop ulcers of the shoulders, and women in brine bath establishments get slight dermatitis (White, 1934). Fresh herring carriers and picklers develop boils and a pyogenic dermatitis on the inner aspect of the forearm (Collis, 1913) and deep, painful ulcers on the knuckles and alongside the nails. In salt factories perforation of the nasal septum and a dry eczema of the skin are described (Schwartz and others, 1947).

Concise accounts of brine dermatitis in the coal-mining industry are rare although the chlorides of natural pit water have been blamed for skin rashes (Fisher, 1944). White (1916) describes an acute eczema of the right hand in a miner which he attributes to the high chloride content of the explosives in constant contact with the skin.

This paper describes an outbreak of industrial dermatitis due to brine during the sinking of a pit shaft, and also contains observations on skin reactions due to a similar cause made over the past three years at another colliery which is in full production.

\section{Environment of Sinkers of a New Shaft}

A major problem in shaft work is the ingress of water, and there are several ways of dealing with it.

This particular shaft was to be sunk through a well known water-bearing stratum, the Bunter Sandstone Bed, and in order to prevent flooding an artificial ice wall was created around the site to a depth of $750 \mathrm{ft}$. Holes were bored peripherally around the shaft area and large pipes inserted; brine at a very low temperature $\left(14^{\circ} \mathrm{F}\right.$.) was circulated, freezing the soil and water to a range of
$6 \mathrm{ft}$. The shaft was then dug in the middle of this area. It is usual to assist the manual excavation by blasting, which requires boreholes sunk to a depth of $7 \mathrm{ft}$. The frozen chippings released by the drill bit tend to refreeze at once and are difficult to evacuate. Compressed air is driven down the centre of the boring bit of the drill to blow them out, and brine, which has a low freezing point, is poured alongside the drill to keep the chippings from refreezing. The holes are filled with brine which is blown out by compressed air jets immediately before inserting the explosive, and the displaced brine liberally sprays the borers. Although 30 men work each shift in the shaft, only 10 of the more experienced bore. The boring shift occurs only irregularly as the shaft walls need consolidation every $100 \mathrm{ft}$. ; thus about 30 men were at risk. Three trained shaft men were employed on the surface to replace absentees among the sinkers ; it is uneconomic to employ more, but this number proved inadequate to cope with increasing incapacity due to dermatitis. The problem was, therefore, acute from its industrial aspect.

\section{Clinical Features of the Shaft-sinking Outbreak}

Eighteen men reported for treatment to the Medical Centre and on several occasions all the men boring were inspected in the pithead baths after the shift. There appeared a fairly constant clinical picture which was similar to that described by Collis in the herring picklers. It consisted of (1) punched-out ulcers of the knuckles; (2) a follicular excoriated dermatitis with well marked erythema on the flexor aspect of the forearm, and a smaller localized area over the humeral origin of the forearm extensors; (3) boils on the flexor surface of the wrist and occasionally on the neck ; (4) three cases showed an excoriated dermatitis of the front of the ankles and shins.

It was considered that the brine (an $8 \%$ solution of calcium chloride) was the cause of the trouble, and this was explained to the men. Jaconet sleeves were 
quickly made and it was significant that the borers wore them regularly and eagerly renewed them when they wore through or were torn. Brine was used sparingly and all skin irritation received early attention. The affected part was scrupulously cleaned and zinc and castor oil cream applied by the first-aid attendant who was available actually at the baths at the end of each shift. The trouble subsided quickly with these measures.

Outbreak of Dermatitis at a Large Colliery

Coal-miners, however, who work on the coal face in pants, vest, stockings, and boots at higher temperatures are often exposed to brine solution and complain of skin irritation. During an investigation prompted by such an occasion, observations were made at a wet face at another colliery in full production over a period of three years. Water was constantly on the floor and intermittently ran from the roof as faults were struck. Analysis of the water showed it to contain :-

$$
\left.\begin{array}{llr}
\mathrm{Ca} \mathrm{Cl}_{2} & \ldots & 51,900 \\
\mathrm{Mg} \mathrm{Cl} & \ldots & 10,200 \\
\mathrm{Na} \mathrm{Cl} & \ldots & 129,500
\end{array}\right\} \text { parts per million }
$$

The coal seam worked was $4 \mathrm{ft}$. 6 in. thick and conditions, apart from the water, were uniformly good and constant. From October 15 to November 14, 1951, hygrometer readings and ventilation speeds were taken daily. The air entered this coal face at a speed of $171.2 \mathrm{ft}$. per second at a dry-bulb temperature of $78.7^{\circ} \mathrm{F}$. and a relative humidity of $52.5^{\circ} \mathrm{F}$. After passing along the face the relative humidity of the air rose to $65 \cdot 1$ while the dry-bulb temperature was $79 \cdot 1^{\circ} \mathrm{F}$.

Approximately the same 100 men worked on this face, of whom 12 were certified as suffering from industrial dermatitis by surgeons of the Ministry of Pensions and National Insurance during the three years. This figure is significant as during the same three years only 24 other cases were certified from this colliery, which has a population of 1,750 men working, of whom approximately 650 are coal-face workers. The distribution of the initial attack of dermatitis in these 12 was on the lower legs, but not extending to the feet and toes (five cases), the inner aspect of the inner forearms but not hands (three cases), shoulders extending along the outer aspect of the upper arm (three cases), and buttocks (one case).

\section{Discussion}

The response to the measures adopted in the shaft sinkers suggested that the calcium chloride was the cause of the trouble. An attempt was made to assess the local irritant effect of the same solution. A gauze pad soaked in the solution was bandaged just above the elbow of seven volunteers from a colliery office. The pad was kept in position for seven days and soaked in the solution each morning. Two complained of itching in the elbow flexure and one developed an erythematous patch studded with a few vesicles. A patch of erythema appeared on the elbow of another patient, but none complained of the skin beneath the pad. The other factor involved was probably friction, although White (1934) and most authorities suggest that crystals must be added to sodium chloride to produce any skin lesions. Nash (1955) describes a coagulative necrosis of the skin of the friction areas of the knees due to a $40 \%$ solution of calcium chloride in a Turkish labourer after one exposure. The lesions in Heppleston's case (1946) were present where the edges of gum boots rubbed the skin of the knees. Friction would explain the distribution of the lesions in the outbreaks described in this paper. The other interesting feature is that the sinkers worked fully clothed at a temperature of $32^{\circ}$ to $36^{\circ} \mathrm{F}$. while the coal-miners worked dressed only in boots, socks, pants, and vest at a much higher temperature.

\section{Summary}

An outbreak of industrial dermatitis due to brine (calcium chloride) is described in sinkers, and an account given of industrial dermatitis due to solutions containing chlorides at another large colliery. The importance of the harmful effects of chlorides is emphasized in view of their increasing use underground to allay the dust.

I wish to thank Mr. E. Bishop and Mr. A. Wadsworth, mining engineers, for their technical assistance in this investigation. I am grateful to Dr. J. M. Rogan, the Chief Medical Officer of the National Coal Board, and Dr. J. T. Watkins, the Divisional Medical Officer, East Midlands Division of the National Coal Board, for their valuable criticism and assistance in the preparation of this paper.

\section{REFERENCES}

Collis, E. L. (1913). Cited by White, R, P. (1934).

Critchley, M. (1943). Shipwreck-Survivors. Churchill, London. Fisher, S. W. (1944). Proc. roy. Soc. Med., 38, 59 Heppleston, A. G. (1946). British Journal of Industrial Medicine, 3, 253 .

Nash, P. H. (1955). Brit. med. J., 1, 586.

Paracelsus (1493-1541). Cited by Schwartz, L., Tulipan, L., and Peck, S. M. (1947).

Ramazzini, B. (1700). De Morbis Artificum Diatriba. Capponi, Modena. Cited by Schwartz, L., Tulipan, L., and Peck, S. M. (1947).

Schwartz, L., Tulipan, L., and Peck, S. M. (1947). Occupational Diseases of the Skin, 2nd ed. Lea and Febiger, Philadelphia.

White, R. P. (1916). Lancet, 1, 403.

Shin The Dermatergoses or Occupational Affections of the 